\title{
СЕРОЛОГІЧНИЙ ПРОФІЛЬ АНТИТІЛ ПРИ СИМПТОМАТИЧНОМУ АУТОІМУННОМУ ГЕМОЛІЗІ
}

\author{
Мироненко Г. А., Павлюк Р. П., Тимошенко У. В. \\ ДУ «Інститут гематології та трансфузіологї НАМН України», \\ Київ, Україна \\ Резюме
}

\begin{abstract}
Bступ. Системні аутоімунні захворювання, інтоксикації, злоякісні новоутворення, вплив медикаментозних препаратів, а також вірусні інфекції, зокрема, SARS-CoV-2, можуть провокувати синтез аутоімунних антиеритрочитарних антитіл (AAAT) з наступним розвитком гемолітичного прочесу.

Мета. Визначити частку захворювань $і$ станів, які проявляються чи ускладнюються аутосенсибілізацією або аутоімунним гемолізом та дати серологічну характеристику виявлених АAT.

Матеріали і методи. Обстежено 46 пацієнтів 3 проявами вторинної аутоімунної гемолітичної анемї або аутосенсибілізації, які розвинулися на тлі злоякісних захворювань системи крові, В12-фолієводефіцитної анемї, аутоімунних захворювань, неконтрольованого прийому лікарських препаратів, токсичних або інфекиійних впливів. Виявлення AT, їх ідентифікацію за класами, підкласами, щільність опсонізації здійснювали мікрометодом в гелевому тесті (BioRad, USA).

Результати. Вторинні аутоімунні гемолітичні реакиії склали 36\% в когорті обстежених хворих на АІГА. При розвитку вторинної АІГА на тлі аутоімунних захворювань (15,2\%) мала місие різноманітна клініко-лабораторна картина: від різко вираженого позасудинного гемолізу з виявленням неповних теплових аглютинінів IgG1 у високій концентрації до серологічного явища аутосенсибілізації. У пачієнтів внаслідок прийому деяких медикаментів, а також токсичних впливів, вірусних інфекцій виявлявся широкий спектр АAAT, їх висока концентрація та схильність до розвитку гемолітичної кризи.

Висновки. Серологічні особливості АААТ впливають на вираженість $і$ клінічний перебіг ГА. Клінічна настороженість щзод можливості розвитку вторинного хронічного аутоімунного гемолізу стосується хронічних вірусних інфекиій та системних аутоімунних захворювань. Гострий разовий епізод гемолізу частіше виникає внаслідок гострих вірусних інфекцій, інтоксикацій, прийому медикаментів.
\end{abstract}

Ключові слова: Аутоімунний гемоліз, фонове захворювання, аутоімунні антиеритроцитарні антитіла. 
Конфлікт інтересів: автори заявляють про відсутність конфлікту інтересів.

Фінансування: дослідження не мало спонсорської підтримки.

\title{
SEROLOGICAL PROFILE OF ANTIBODIES IN SYMPTOMATIC AUTOIMMUNE HEMOLYSIS
}

\author{
Myronenko H. A., Pavlyuk R. P., Tymoshenko U. V. \\ SI «Institute of Haematology and Transfusiology of NAMS of Ukraine», \\ Kyiv, Ukraine
}

\begin{abstract}
Introduction. Systemic autoimmune diseases, intoxications, malignancies, drug effects, and viral infections, in particular SARS-CoV-2, can provoke the synthesis of autoimmune anti-erythrocyte antibodies with the subsequent development of the hemolytic process.

Aim. Determine the proportion of diseases and conditions that are manifested or complicated by autosensitization or autoimmune hemolysis and give a serological description of the detected autoimmune anti-erythrocyte antibodies.

Materials and methods. Examined 46 patients with manifestations of secondary AIHA or autosensitization, which developed on the background of malignant diseases of the blood system, B12-folate deficiency anemia, autoimmune diseases, uncontrolled medication, toxic or infectious effects. Detection of antibodies, their identification by classes, subclasses, opsonization density was carried out by micromethod in a gel test (BioRad, USA).

Results. Secondary autoimmune hemolytic reactions accounted for 36\%. With the development of secondary AIGA on the background of autoimmune diseases $(15.2 \%)$, there was a diverse clinical and laboratory picture: from severe extravascular hemolysis with the detection of incomplete thermal agglutinins IgG1 in high concentrations to the serological phenomenon of autosensitization. Patients with drug and toxic effects, viral infections showed a wide range of autoimmune anti-erythrocyte antibodies, their high concentration and susceptibility to hemolytic crisis.

Conclusions. Serological features of autoimmune anti-erythrocyte antibodies affect the severity and clinical course of HA. Clinical concern about the possibility of developing secondary chronic autoimmune hemolysis applies to chronic viral infections and systemic autoimmune diseases. Acute single episode of hemolysis more often occurs with drug exposure, intoxication, acute viral infections.
\end{abstract}

Keywords: autoimmune hemolysis, background disease, autoimmune anti-erythrocyte antibodies. 


\section{Вступ}

Аутоімунний гемоліз може ускладнювати перебіг багатьох захворювань та станів, у тому числі негематологічного профілю. Як показує світова медична практика, при ретельному обстеженні пацієнта 3 ознаками аутоімунного гемолізу в 20-80\% випадків можна виявити фонове захворювання, ускладненням або проявом якого, іноді єдиним, є аутоімунна гемолітична анемія (АІГА) $[1,2]$. Як правило, настороженість фахівців щодо можливих аутоімунних гемолітичних ускладнень стосується лімфопроліферативних захворювань, В-12 та фолієводефіцитної анемії, системних захворювань сполучної тканини, злоякісних новоутворень. Проте не слід оминати увагою можливість їх виникнення при інфекційних процесах, таких як вірусні гепатити, ВІЛ, інфекційний мононуклеоз, цитомегаловірусна інфекція, весь спектр дитячих інфекційних хвороб [1]. Актуальність цієї проблеми підтверджують дані про виникнення перших епізодів АІГА серед пацієнтів з інфекцією SARS-CoV-2 в терміни, співставні $з$ періодом цитокінового шторму [3]. Досить часто аутоімунні гемолітичні процеси стають ускладненням медикаментозної терапії перелік відомих лікарських засобів, здатних викликати гемоліз містить близько двох сотень найменувань, у тому числі чимало загальновживаних нерецептурних засобів [4-6].

Мета. Визначити частку захворювань і станів, які проявляються чи ускладнюються аутосенсибілізацією або аутоімунним гемолізом та дати серологічну характеристику виявлених аутоімунних антиероцитарних антитіл.

\section{Матеріали і методи}

У дослідження включено 128 хворих на набуту імунну гемолітичну анемію (із встановленим діагнозом АІГА, а також направлених для уточнення діагнозу з підозрою на аутоімунний гемоліз), з різним ступенем вираженості клініко-лабораторних ознак гемолітичного процесу та позитивними тестами виявлення аутоімунних антиеритроцитарних антитіл (АААТ), код захворювання згідно Міжнародної класифікації хвороб 11-го перегляду - 3А20.0-3А20.2.

3 них виділено і обстежено 46 пацієнтів 3 проявами вторинної АІГА або аутосенсибілізації, які розвинулися на тлі злоякісних захворювань системи крові, В12-фолієводефіцитної анемії, системних аутоімунних захворювань, неконтрольованого прийому лікарських препаратів, токсичних або інфекційних впливів. Спектр ознак гемолізу у цих пацієнтів варіював від класичних проявів гемолітичної кризи (ГК) до явища аутосенсибілізації (АС) - наявності АААТ за відсутності типових клініко- 
лабораторних ознак гемолізу. Усім їм лабораторно підтверджено аутоімунний характер захворювання шляхом встановлення наявності АAАТ і ї серологічного варіанту: теплових, холодових аглютинінів (XА)/гемолізинів та змішаних форм (табл. 1).

Дослідження проводилися у рамках НДР, що виконувалася в ДУ «Інститут гематології та трансфузіології НАМН України». У дослідження також були включені хворі з АІГА, яким проводилися імуногематологічні дослідження в термін з 2016 по 2021 роки. При плануванні робіт були отримані позитивні рішення комітету з медичної етики інституту щодо відповідності дотримання етичних стандартів у наукових дослідженнях із залученням людини, що відповідає принципу Гельсінської Декларації «Етичні принципи медичних досліджень за участю людини у якості об'єкта дослідження», Конвенції Ради Європи про захист прав та гідності людини в зв'язку із застосуванням досягнень біології та медицини та відповідним Законам України. Пацієнти, які були обстежені, надали письмову інформовану згоду на участь у наукових клінічних дослідженнях (випробуваннях).

Виявлення АААТ, їх ідентифікацію за класами, підкласами, щільність опсонізації еритроцитів, а також встановлення наявності продуктів деградації комплементу проводили у непрямому антиглобуліновому тесті (пробі Кумбса) мікрометодом в гелевому тесті (BioRad, USA). Для визначення аглютинінових форм АAAT використовували ID-картки: LISS/Coombs (IgG+C3d) - для теплових антитіл (AT) класу IgG у тестах Кумбса; $\mathrm{NaCl}$, enzyme test and cold agglutinins - для холодових аглютинінів класу IgM; ідентифікацію АТ за класами проводили на ID-картках DC-Screening I (визначення IgG, IgA, IgM та C3c, C3d компонентів комплементу) [7], Для визначення субкласів IgG та їх титру (оцінка ризику гемолізу) застосовували ID-картки DAT IgG1/IgG3 з двома розведеннями (1:11:100(Anti-IgG1) - 1:1-1:100(Anti-IgG3) - ctl- 1:10(Anti-IgG)).

Для визначення аутоімунних кислотних гемолізинів ми застосовували модифікований класичний метод їх виявлення, на що отримано відповідний патент [8]. Запропонований мікрометод полягає в мінімізації об'єму затратного матеріалу при збереженні суті та інформативності реакції. Це досягається шляхом зменшення об'єму компонентів реакції у 5 разів, застосуванням мікропробірок об'ємом 0,5 мл 3 витягнутим конусним дном для покращення сепарації осаду, м'якого режиму центрифугування для зменшення навантаження на клітинну мембрану.

Статистичний аналіз отриманих результатів здійснювали за допомогою пакета статистичних програм StatSoft STATISTICA 10.0.1011. Для 
опису розподілень використано елементи непараметричної статистики: міру центральної тенденції Ме (медіана) та міру розсіювання (квартильний розмах). Для оцінки достовірності розбіжностей кількісних ознак між двома незалежними групами застосовували непараметричний метод статистичного аналізу U-критерій Мана-Уітні.

\section{Результати та їх обговорення}

Із 128 випадків АІГА, що спостерігались нами з 2009 по 2021 роки, вторинні аутоімунні гемолітичні реакції становили 36\% (46 пацієнтів).

Серед цих хворих найбільшу частку склали пацієнти зі злоякісними захворюваннями крові - 20 осіб (43,5 \%). Основною нозологією серед них була В-клітинна хронічна лімфоцитарна лейкемія - 9 випадків. Для більшості пацієнтів (6 осіб) були характерні наявність IgG-неповних теплових аглютинінів та високий/помірний ризик гемолізу, що серологічно підтверджувалося виявленням IgG1 i/або IgG3 в розведенні 1:100 або 1:1 i виразністю реакції аглютинації в прямій пробі Кумбса на «3+» або «4+». Серед хворих на В-ХЛЛ спостерігався один випадок виявлення патологічних холодових аглютинінів (з широким температурним діапазоном дії 4-32 ${ }^{\circ} \mathrm{C}$ і високим титром 1:64) та по одному випадку виявлення холодових і теплових аутоімунних кислотних гемолізинів. Наявність аглютинінових форм АААТ у цих хворих супроводжувалася вираженим або помірним анемічним синдромом i біохімічними ознаками позасудинного гемолізу (для теплових форм) і внутрішньосудинного гемолізу (для холодових форм). При гемолізинових формах антитіл у хворих на В-ХЛЛ анемї̈ не спостерігалося.

У 5 хворих фоновим захворюванням була В-НХЛ. Типовими для таких пацієнтів були слабко виражені аутоантитіла (реакція Кумбса < «2+»), які відносилися до теплових аглютинінів (у 3 осіб) та гемолізинів (у 2 осіб), за відсутності клініко-лабораторних ознак анемії та гемолізу.

При дослідженні європейськими спеціалістами випадків вперше діагностованої АІГА (ГК), що ускладнювала перебіг коронавірусної хвороби, викликаної SARS-CoV-2, у більшості хворих встановили наявність недіагностованої супутньої гематологічної патології. Серед них: ХЛЛ (стадія А по Binet), моноклональна гамапатія IgG kappa невстановленого генезу асоціювалися у більшості хворих із наявністю теплових аглютинінових форм ААТ, 2/3 випадків із встановленими холодовими аглютиніновими формами ААТ асоціювались із лімфомою маргінальної зони [3].

При інших формах злоякісних захворювань крові (6 осіб) також виявлялися АААТ. При цьому найбільш яскраво клініко-лабораторні ознаки 
гемолізу були виражені у пацієнта 3 хворобою Вальденстрема, у якого були виявлені комбіновані антитіла (теплові аглютиніни IgG3 з високою щільністю покриття еритроцитів і патологічні холодові аглютиніни в титрі 1:512, активні при температурі $20^{\circ} \mathrm{C}$ ). У решти хворих спостерігалися неповні теплові аглютиніни в низькій концентрації (ХМЛ, остеомієлофіброз), комплементарний тип проби Кумбса (МДС), кислотні гемолізіни (В-ГЛЛ) та холодові аглютиніни (ГЛЛ). Інші клініко-лабораторні ознаки гемолізу у цих хворих, крім пацієнта 3 хворобою Вальденстрема, були мінімальні або відсутні зовсім.

Другою за чисельністю групою 3 вторинною гемолітичною реакцією були хворі 3 хронічною формою вірусного гепатиту $\mathrm{C}-7$ пацієнтів $(15,2$ \%), 3 яких 5 було ушпиталено 3 приводу ГК з яскраво вираженими клініко-лабораторними ознаками позасудинного гемолізу 3 наявністю теплових аглютинінів класу IgG у високій концентрації (в розведенні 1:100-1:1000) i різко позитивного прямого антиглобулінового тесту $(« 4+»)$. У решти пацієнтів визначався слабопозитивний тест Кумбса без будь-яких ознак гемолізу («<2+»).

Ще у 7 випадках, що також склало 15,2 \%, вторинна АІГА розвинулася на тлі аутоімунних захворювань: системний червоний вовчак, васкуліт, тиреоїдит, гепатит, аутоімунний поліорганний синдром, і характеризувалася різноманітною клініко-лабораторною картиною: від різко вираженого позасудинного гемолізу з виявленням теплових аглютинінів IgG1 у високій концентрації і виразністю проби Кумбса на «4+» (у 5 пацієнтів) до виключно серологічного явища $\mathrm{AC}$ - відсутністю клініко-лабораторних ознак гемолізу при виразності прямого антиглобулінового тесту на «1+». При динамічному спостереженні частини таких хворих спостерігалась схильність до хронізації процесу, з періодами активації та згасання гемолізу, повної редукції ААТ не було відмічено.

На особливу увагу заслуговує виникнення вторинної АІГА внаслідок впливу медикаментів та токсичних речовин. У 5 осіб (10,9 \% від загальної кількості пацієнтів) гемоліз розвинувся на тлі неконтрольованого прийому препаратів (парацетамол, цефтриаксон), а також внаслідок впливу випаровувань лако-фарбових матеріалів. Відмінною рисою в цій групі хворих був швидкий розвиток ГК і виявлення неповних теплових IgG1 та/або IgG3 у високій концентрації (1:1000), у двох випадках - у поєднанні 3 холодовими IgM. Усі вказані гемолітичні реакції фіксувалися тільки у пацієнтів підліткового та молодого віку, двоє з яких померли.

Аутоімунні гемолітичні реакції, як наслідок вірусної інфекції, спостерігалися у трьох дітей $8-12$ років (6,5 \% загального числа хворих) на тлі 
ГРВI, інфекційного мононуклеозу у вигляді ГК. Виявлені у них АAАТ належали до різних класів - IgG1 неповним аглютинінам, IgM патологічним холодовим аглютинінам, тепловим кислотним гемолізинам, які визначалися у високих титрах. По мірі одужання пацієнтів від інфекції під впливом специфічного лікування кількість АААТ швидко знижувалася, нормалізувався загальний стан і лабораторні показники. Процес не був схильний до хронізації і через 4-5 тижнів АААТ уже не виявлялися.

У трьох пацієнтів $(6,5 \%)$ вторинні гемолітичні реакції ускладнили перебіг $\mathrm{B}_{12}$-фолієводефіцитної анемії. На тлі яскравої картини ГК визначалися теплові аглютиніни IgG1 у високих концентраціях (1:1000).

У однієї пацієнтки аутоімунний гемоліз виник на фоні злоякісного новоутворення малого таза. Спостерігалася помірна активність гемолізу (пряма проба Кумбса «3+», щільність опсонізації IgG1 відповідала розведенню 1:1).

Серологічна характеристика АААТ при вторинному аутоімунному гемолізі наведена в таблиці 1.

\section{Таблиця 1. Серологічні варіанти та особливості антиеритроцитарних антитіл у хворих з вторинним аутоімунним гемолізом}

\begin{tabular}{|c|c|c|c|c|}
\hline \multirow[b]{2}{*}{ Показник } & \multicolumn{4}{|c|}{ Аутоімунні антиеритроцитарні антитіла } \\
\hline & $\begin{array}{c}\text { Теплові } \\
\text { аглютиніни } \\
(\mathbf{n}=\mathbf{3 3})\end{array}$ & $\begin{array}{c}\text { Холодові } \\
\text { аглютиніни } \\
(\mathbf{n}=3)\end{array}$ & $\begin{array}{c}\text { Змішаний } \\
\text { тип } \\
(\mathrm{n}=4)\end{array}$ & $\begin{array}{c}\text { Гемолізини } \\
\text { теплові/ } \\
\text { холодові } \\
(\mathbf{n}=6)\end{array}$ \\
\hline $\begin{array}{l}\text { Частота } \\
\text { виявлення }\end{array}$ & $71,7 \%$ & $6,5 \%$ & $8,8 \%$ & $13 \%$ \\
\hline $\begin{array}{l}\text { Прямий анти- } \\
\text { глобуліновий } \\
\text { тест }\end{array}$ & $\begin{array}{l}\mathrm{IgG} \pm \mathrm{C} 3 \mathrm{~d} \\
\text { зрідка C3d }\end{array}$ & $\begin{array}{c}\text { C3d; } \\
\text { зрідка С3c }\end{array}$ & $\operatorname{IgG} \pm \mathrm{C} 3 \mathrm{~d} / \mathrm{C} 3 \mathrm{c}$ & C3d \\
\hline $\operatorname{Ig}$ & $\begin{array}{c}\text { IgG1/IgG3, } \\
\text { рідко - IgA } \\
\text { чи IgM }\end{array}$ & IgM & $\begin{array}{c}\text { IgG1/IgG3, } \\
\text { IgM }\end{array}$ & $\operatorname{IgG}$ \\
\hline
\end{tabular}

Усім хворим 3 позитивною пробою Кумбса інтенсивністю «3+/4+» визначали підклас ААAT, а також щільність опсонізації IgG1 та/або IgG3 для оцінки ризику гемолізу згідно інструкції виробника для відповідних ID-карток. Результати дослідження подані в таблиці 2. 
Таблиця 2. Щільність опсонізації поверхні еритроцитів та вміст непрямого білірубіну як показника екстраваскулярного гемолізу при вторинному аутоімунному гемолізі

\begin{tabular}{|c|c|c|c|}
\hline Показник & $\begin{array}{c}\text { Низький } \\
\text { ризик } \\
\text { гемолізу }(n=9)\end{array}$ & $\begin{array}{l}\text { Середній } \\
\text { ризик } \\
\text { гемолізу } \\
(n=4)\end{array}$ & $\begin{array}{l}\text { Високий ризик } \\
\text { гемолізу }(n=20)\end{array}$ \\
\hline $\begin{array}{l}\text { Прямий анти глобуліно- } \\
\text { вий тест } з \text { полі специ- } \\
\text { фічним АГС (IgG+C3d) }\end{array}$ & $<2+$ & \multicolumn{2}{|c|}{$\geq 2+$} \\
\hline IgG-IgA-IgM-C3c-C3d & $<2+(\operatorname{IgG})$ & \multicolumn{2}{|c|}{$\geq 2+(\operatorname{IgG})$, іноді в комбінації з $\operatorname{IgM}$ та IgA } \\
\hline $\begin{array}{l}\text { IgG у розведеннях } 1: 10- \\
1: 30-1: 100-1: 300-1: 1000\end{array}$ & $=<30$ & \multicolumn{2}{|c|}{$\geq 30$} \\
\hline $\begin{array}{l}\text { IgG1/IgG3 IgG y } \\
\text { розведеннях 1:1-1:100 }\end{array}$ & Не виявляє & Позит. 1:1 & Позит. 1:100 \\
\hline $\mathrm{Hb}-\mathrm{Me}(25 \% ; 75 \%)$, г/л & $103(97 ; 111)$ & $90(86,5 ; 109,5)$ & $64,5(50,5 ; 80,5)^{*}$ \\
\hline $\operatorname{Er}-\operatorname{Me}(25 \% ; 75 \%), \mathrm{T} / л$ & $3,3(3,1 ; 3,7)$ & $3,05(2,65: 3,25)$ & $1,93(1,5 ; 2,2)^{* *}$ \\
\hline $\begin{array}{l}\text { Непрямий білірубін - } \\
\text { Me (25\%;75\%), мкмоль/л }\end{array}$ & $19,0(12,1 ; 22,0)$ & $34,2(26,9 ; 45,25)^{* * *}$ & $72,0(49,5 ; 89,0)^{* *}$ \\
\hline
\end{tabular}

Примімки: "- $\mathrm{p}<0,01$ між 2 та 3 групами; ${ }^{* *}-\mathrm{p}<0,01$ між 2 та 3 групами; *** $-\mathrm{p}<0,01$ між 1 та 2 групами

У 20 пацієнтів діагностовано високий ризик гемолізу, що відповідало високій щільності покриття мембрани еритроцита АААТ, - вони виявлялись у розведенні 1:100 і відносились до IgG1 та/або IgG3. У 9 пацієнтів виявлені AT IgG1 та/або IgG3 у розведенні 1:1 (низька щільність), що вказує на помірний ризик гемолізу. У решти хворих (переважно при гемобластозах) щільність АААТ не встановлено через низьку вираженість проби Кумбса $(« 1+/ 2+»)$ або через іï комплементарний тип (реакція позитивна за рахунок виявлення продуктів деградації комплементу С3d та/або С3c). У таких пацієнтів ступінь ризику гемолізу був мінімальним.

Зв'язок між високою щільністю покриття еритроцитів АААТ і розвитком анемічного синдрому, як проявом гемолізу виявлено лише у групі хворих з високим ступенем ризику гемолізу (високою щільністю АТ) встановлена достовірна різниця між 2 та 3 групами за вмістом гемоглобіну $(\mathrm{Hb})(\mathrm{p}<0,01)$ та кількістю еритроцитів $(\mathrm{p}<0,01)$. Аналогічного зв'язку не виявлено у групах із низьким та високим ступенем ризику гемолізу 
(достовірної різниці за показниками гемоглобіну та кількістю еритроцитів не встановлено). У сучасних наукових працях обережно трактують залежність інтенсивності гемолізу від щільності ААТ на поверхні еритроцитів, спонукаючи не відкидати значення вираженості реакції аглютинації в класичному прямому антиглобуліновому тесті [9]. Оцінюючи отримані дані, ми взяли до уваги, що аутоімунний гемоліз у нашому дослідженні був ускладненням основного захворювання (часто онкогематологічного), тому виникнення анемії у першу чергу могло провокуватися саме ним, і тільки критично висока концентрація АТ на еритроцитах виводила на перший план аутоімунний механізм гемолізу при прогресуванні анемічного синдрому, що часто проявлялося розвитком ГК. У той же час, вміст непрямого білірубіну, як показника екстраваскулярного гемолізу, чітко демонструє залежність інтенсивності деструкції еритроцитів від щільності АААТ на мембрані (табл. 2). Так, виявлена достовірна відмінність між 1 та 2, 2 та 3 групами спостереження за цим показником $(\mathrm{p}<0,01)$. Описаний показник ми пропонуємо враховувати при оцінці інтенсивності аутоімунного гемолізу саме при симптоматичних формах АІГА з тепловими аглютинінами, коли є підстави вважати анемічний синдром багатофакторним.

Патологічні холодові аглютиніни при симптоматичному гемолізі зустрічалися вкрай рідко (табл. 1) і мали відповідні серологічні характеристики (табл. 3).

Таблиця 3. Залежність рівня гемоглобіну від серологічної характеристики холодових аглютинінів

\begin{tabular}{|c|c|c|c|c|c|}
\hline $\begin{array}{c}\text { Варiaнт } \\
\text { AT }\end{array}$ & $\begin{array}{c}\text { Клас } \\
\text { Ig }\end{array}$ & $\begin{array}{c}\text { Темпера- } \\
\text { турний } \\
\text { діапазон дії } \\
\text { IgM } \\
\end{array}$ & $\begin{array}{c}\text { Титр } \\
\text { холодових } \\
\text { аглютинінів }\end{array}$ & $\begin{array}{l}\text { Пряма } \\
\text { проба } \\
\text { Кумбоса }\end{array}$ & $\begin{array}{c}\text { Вміст Нb } \\
\text { Me }(25 \% ; 75 \%), \\
\text { Г/л }\end{array}$ \\
\hline \multirow{2}{*}{$\begin{array}{l}\text { Холодові } \\
\text { аглютиніни } \\
(\mathrm{n}=3)\end{array}$} & \multirow[t]{2}{*}{$\operatorname{IgM}$} & $4-12{ }^{\circ} \mathrm{C}$ & 1:64-1:4096 & $\begin{array}{c}\text { C3d, C3c } \\
\text { або } \\
\text { негативна }\end{array}$ & \multirow[t]{2}{*}{$97,7(91,9 ; 103,2)$} \\
\hline & & $4-32{ }^{\circ} \mathrm{C}$ & $1: 2-1: 512$ & $\mathrm{C} 3 \mathrm{~d}$ & \\
\hline $\begin{array}{l}\text { Змішаний } \\
\text { варіант } \\
\text { (холодові+ } \\
\text { теплові АГ) } \\
(\mathrm{n}=4)\end{array}$ & $\begin{array}{l}\text { IgM+ } \\
\text { IgG }\end{array}$ & $4-12{ }^{\circ} \mathrm{C}$ & $1: 4-1: 256$ & C3d, IgG & $50,4(42,2 ; 67,0)^{*}$ \\
\hline
\end{tabular}

Примітка: ${ }^{*}-\mathrm{p}=0,03$, по відношенню до групи хворих з холодовими аутоантитілами. 
У чотирьох пацієнтів виявлена комбінація теплових (IgG) та холодових аглютинінів (IgM) - змішаний серологічний варіант АІГА. Пряма і непряма проби Кумбса виявили теплові IgG та C3d компонент комплементу. Водночас спостерігали патологічні ХА із помірною температурною активністю: за температури $4^{\circ} \mathrm{C}$ - у титрі від 1:64 до 1:256, при $12^{\circ} \mathrm{C}$ - від 1:4 до 1:32. Клінічно ГА характеризувалася агресивним перебігом, із нашаруванням ознак внутрішньо- і позасудинного гемолізу, що проявлялося нормохромною аннемією середнього або важкого ступеня тяжкості, ретикулоцитозом, підвищенням рівня непрямого білірубіну, зниженням осмотичної резистентності еритроцитів, мав місце один летальний випадок. Рівень Нb у цих пацієнтів був достовірно нижчим ( $\mathrm{p}=0,03)$, ніж у випадках наявності ізольованих патологічних холодових АААТ. ГА у вищеописаних хворих була медикаментозноіндукована або як ускладнення хвороби Вальденстрема i В-ХЛЛ. Сучасні наукові публікації також наголошують на більш інтенсивному характері гемолізу, спричиненого такою комбінацією АТ та необхідністю пошуку фонових захворювань [10]. Проте, для здійснення глибшого аналізу необхідно провести більшу кількість спостережень.

У $13 \%$ хворих аутоімунний гемоліз був зумовлений гемолізиновими формами АТ, переважно їх тепловим варіантом. Майже у всіх випадках це явище виникало на фоні злоякісних захворювань крові: В-ХЛЛ, В-НХЛ, В-ГЛЛ. Показники вмісту Нb та кількості еритроцитів коливались від нормальних до анемії середнього ступеня тяжкості. Так, середній рівень $\mathrm{Hb}$ - Me (25\%; $75 \%)$ становив 99,1 (73,2; 132,7) г/л, еритроцитів - 3,3 $(2,81 ; 4,39)$ Т/л. Лабораторні дані свідчать про інтраваскулярний варіант гемолізу - вміст гаптоглобіну в усіх випадках був нижчим від вікових норм, рівень вільного $\mathrm{Hb}$ - підвищений до $0,35(0,12 ; 0,74)$ г/л, тоді як рівень непрямого білірубіну не перевищував нормальних показників. Проба Кумбса була позитивна в одному випадку - за рахунок виявлення C3d-компонента комплементу. Такий серологічний варіант АІГА часто вислизає з поля зору клініциста, оскільки традиційний антиглобуліновий тест не виявляє гемолізинові форми ААТ [11], тому є необхідність в спеціальних громіздких реакціях, які в класичному варіанті потребують значної кількості крові пацієнта (близько 6-7 мл), тому нами було розроблено мікрометод виявлення цього серологічного різновиду АAАТ [8].

Таким чином, розширення спектру методів клініко-лабораторної та інструментальної діагностики дозволить все рідше кваліфікувати аутоімунні гемолітичні реакції як ідіопатичні, а своєчасна діагностика основного захворювання сприятиме патогенетично обгрунтованому лікуванню пацієнта з проявами аутоімунного гемолізу. 


\section{Висновки}

1. Аутоімунні гемолітичні реакції у $50 \%$ випадків були ускладненням захворювань системи крові: переважно злоякісних (43,5 \%), значно рідше $(6,5 \%)-B_{12}$-фолієводефіцитної анемії. Найчастішою нозологією, яка ускладнювалася симптоматичним аутоімунним гемолізом була В-ХЛЛ (19,7\% серед усіх обстежених нами хворих і, відповідно, $45 \%$ серед хворих на злоякісні захворювання системи крові з виявленою ГА).

2. Частка аутоімунних, інфекційних, ендокринних захворювань, злоякісних новоутворень, а також аутоімунних гемолітичних ускладнень внаслідок впливу лікарських препаратів, токсичних речовин $є$ не менш вагомою (50 \%), що потребує уваги інших вузькопрофільних фахівців та залучення, за необхідності, спеціалістів-гематологів.

3. Детальне серологічне обстеження цих хворих демонструє широкий спектр виявлених АААТ (71,4 \% - теплові аглютинінові форми, 6,5\% холодові аглютинінові форми, змішаний варіант - 8,8\%, гемолізини 13 \%). Їхні серологічні особливості впливають на вираженість і клінічний перебіг гемолітичного процесу, вибір відповідної тактики лікування.

4. При симптоматичних формах АІГА оцінка ролі аутоімунного гемолітичного компоненту у прогресуванні анемічного синдрому є ускладненою та потребує комплексного підходу із залученням визначення щільності опсонізації еритроцитів АТ, вмісту непрямого білірубіну (для теплових аглютинінових форм), титру та температурного оптимуму дії ХА та вмісту гаптоглобіну (для холодових аглютинінів та гемолізинових форм ААТ).

5. Найбільш агресивний перебіг вторинного гемолітичного процесу (гемолітична криза) відзначався у $100 \%$ пацієнтів, які зазнали впливу токсичних хімічних речовин або медикаментів, $\mathrm{B}_{12}$-фолієводефіцитною анемією та у дітей з вірусними інфекціями, а також по 71,4\% у хворих 3 хронічною формою гепатиту $\mathrm{C}$ або фоновою аутоімунною патологією (системний червоний вовчак, васкуліт, тиреоїдит, гепатит, аутоімунний поліорганний синдром).

6. Клінічна настороженість щодо можливості розвитку вторинного хронічного аутоімунного гемолізу стосується хронічних вірусних інфекцій та системних аутоімунних захворювань. Гострий разовий епізод гемолізу частіше виникав внаслідок гострих вірусних інфекцій, інтоксикацій, прийому медикаментів. 


\section{Література}

1. Greer JP, Arber DA., Glader B, List AF, Means RT, Paraskevas F, Rodgers GM, et al Wintrobe's clinical hematology. 13th ed. Philadelfia: Lippincott Williams \& Wilkins; 2014. p. 746-808.

2. Guseva SA, Goncharov YaP. Autoimmune hemolytic anemia: diagnosis and treatment (lecture). Ukrainian Journal of Hematology and Transfusiology. 2012; 1:34-50.

3. Lazarian G, Quinquenel A, Bellal M, Siavellis J, Jacquy C, Re D, et al. Autoimmune haemolytic anaemia associated with COVID-19 infection. Br J Haematol. 2020 Jul; 190(1):29-31.

4. Arndt PA, Leger RM, Garratty G. Serologic characteristics of ceftriaxone antibodies in 25 patients with drug-induced immune hemolytic anemia. Transfusion. 2012 Mar; 52(3): 602-12.

5. Leger RM, Garratty G. Antibodies to oxaliplatin, a chemotherapeutic, are found in plasma of healthy blood donors. Transfusion. 2011 Aug; 51(8): 1740-4.

6. Arndt PA, Garratty G, Wolf CF, Rivera M. Haemolytic anaemia and renal failure associated with antibodies to trimethoprim and sulfamethoxazole. Transfus. Med. 2011 Jun; 21(3): 194-8.

7. Минеева НВ. Группы крови человека. 2е изд. СПб: ООО «А-принт»; 2010. $188 \mathrm{c}$.

8. Павлюк РП, Тимошенко УВ, Мироненко ГА, Лавровська ЛН, винахідники; ДУ «Інститут гематології та трансфузіології НАМН України», патентовласник. Спосіб визначення монофазних автоімунних

\section{References}

1. Greer JP, Arber DA., Glader B, List AF, Means RT, Paraskevas F, Rodgers GM, et al Wintrobe's clinical hematology. 13th ed. Philadelfia: Lippincott Williams \& Wilkins; 2014. p. 746-808.

2. Guseva SA, Goncharov YaP. Autoimmune hemolytic anemia: diagnosis and treatment (lecture). Ukrainian Journal of Hematology and Transfusiology. 2012; 1:34-50.

3. Lazarian G, Quinquenel A, Bellal M, Siavellis J, Jacquy C, Re D, et al. Autoimmune haemolytic anaemia associated with COVID-19 infection. Br J Haematol. 2020 Jul; 190(1):29-31.

4. Arndt PA, Leger RM, Garratty G. Serologic characteristics of ceftriaxone antibodies in 25 patients with drug-induced immune hemolytic anemia. Transfusion. 2012 Mar; 52(3): 602-12.

5. Leger RM, Garratty G. Antibodies to oxaliplatin, a chemotherapeutic, are found in plasma of healthy blood donors. Transfusion. 2011 Aug; 51(8): 1740-4.

6. Arndt PA, Garratty G, Wolf CF, Rivera M. Haemolytic anaemia and renal failure associated with antibodies to trimethoprim and sulfamethoxazole. Transfus. Med. 2011 Jun; 21(3): 194-8.

7. Mineeva NV. Human blood groups. 2th ed. St. Petersburg: OOO «A-print»; 2010. 188 p. (In Russian).

8. Pavliuk RP, Tymoshenko UV, Myronenko HA, Lavrovska LN, vynakhidnyky; DU «Instytut hematolohii ta transfuziolohii NAMN Ukrainy», patentovlasnyk. Sposib vyznachennia monofaznykh avtoimunnykh kyslot- 
кислотних теплових та холодових гемолізинів мікрометодом. Патент України № 99298. 2015 трав. 25.

9. Lai M, Leone G, Landolfi R. Autoimmune hemolytic anemia with gelbased immunohematology tests. Am. J. Clin. Pathol. 2013 Apr; 139(4): 457-63.

10. Barcellini W, Fattizzo B, Zaninoni A, Radice T, Nichele I, Di Bona E, et al. Clinical heterogeneity and predictors of outcome in primary autoimmune hemolytic anemia: a GIMEMA study of 308 patients. Blood. 2014 Nov 6; 124(19): 2930-6.

11. Berentsen S, Tjønnfjord GE. Diagnosis and treatment of cold agglutinin mediated autoimmune hemolytic anemia. Blood. Rev. 2012 May; 26(3): 107-15. nykh teplovykh ta kholodovykh hemolizyniv mikrometodom. Patent Ukrainy № 99298. 2015 trav. 25.

9. Lai M, Leone G, Landolfi R. Autoimmune hemolytic anemia with gelbased immunohematology tests. Am. J. Clin. Pathol. 2013 Apr; 139(4): 457-63.

10. Barcellini W, Fattizzo B, Zaninoni A, Radice T, Nichele I, Di Bona E, et al. Clinical heterogeneity and predictors of outcome in primary autoimmune hemolytic anemia: a GIMEMA study of 308 patients. Blood. 2014 Nov 6; 124(19): 2930-6.

11. Berentsen S, Tjønnfjord GE. Diagnosis and treatment of cold agglutinin mediated autoimmune hemolytic anemia. Blood. Rev. 2012 May; 26(3): 107-15.

Стаття надійшла 16.08.2021

Контакти: immunogematolog@gmail.com 